\title{
Effect of processing methods on antinutrients in selected leafy vegetables
}

\author{
Adeboye A.S. ${ }^{* *}$ and Babajide J. $\mathbf{M}^{2}$. \\ ${ }^{1}$ Department of Food Science and Technology \\ ${ }^{1}$ Moshood Abiola Polytechnic, P.M.B. 2210, Abeokuta, Nigeria. \\ ${ }^{2}$ Department of Food Science and Technology \\ ${ }^{2}$ University of Agriculture, P.M.B. 2240, Abeokuta, Nigeria. \\ *Address for correspondence E -mail:dola_adeboye@yahoo.com
}

ABSTRACT

\begin{abstract}
The effect of different processing methods on the reduction of selected anti-nutrients in 'Ewuro' (Vernonia amygdalina), 'Igbo' (Solanum macrocarpon), 'Ugwu' (Talferia occidentalis) and 'Utazi' (Marsdenia latifolium) was assessed. The treatments/processing methods used for the assessment were $\mathrm{T}_{1}$ (Squeezing vegetable with salt and water only), $\mathrm{T}_{2}$ (Hot water blanching with salt only) $\mathrm{T}_{3}$ (Squeezing with salt, palm oil and water) and $\mathrm{T}_{4}$ (Heating with potash and water only). Results obtained indicated significant differences $(\mathrm{p}<0.05)$ in all the anti-nutrients of all the selected vegetables. For oxalate, saponin, tannin
\end{abstract}

and phytate respectively: 'Ewuro' $-75.36 \mathrm{mg} / \mathrm{g}, 0.079 \%$, $27.33 \mathrm{mg} / \mathrm{g}$ and $55.24 \mathrm{mg} / \mathrm{g}$, 'Igbo' $-84.78 \mathrm{mg} / \mathrm{g}, 0.065 \%$, $23.85 \mathrm{mg} / \mathrm{g}$ and $58.81 \mathrm{mg} / \mathrm{g}$, 'Utazi' - $95.36 \mathrm{mg} / \mathrm{g}, 0.092 \%$, $19.67 \mathrm{mg} / \mathrm{g}$ and $53.20 \mathrm{mg} / \mathrm{g}$, Ugwu $-75.81 \mathrm{mg} / \mathrm{g}, 0.057 \%$, $21.05 \mathrm{mg} / \mathrm{g}$ and $60.80 \mathrm{mg} / \mathrm{g}$. Treatments $\mathrm{T}_{4}$, gave the highest reduction of oxalate, saponin, tannin and phytate contents of all the selected vegetables and was recommended as a means of reducing the selected anti-nutrients.

Keywords: Leafy vegetables, antinutrients, treatments/ processing methods

\section{INTRODUCTION}

$\mathrm{V}$ egetables and fruits offer the most rapid and lowest cost method of providing adequate supplies of vitamins, minerals, calcium and fiber to the people who lives in the tropics (Ihekoronye and Ngoddy, 1985). They have a high content of water and abundance of cellulose. The cellulose is in a form which although not digested, serves a useful purpose in the intestine as roughages, thus promoting normal elimination of waste product. Green leafy vegetables are common and integral feature in Nigerian staples with choice of use and culinary processing varying across the socio-ethnic groups in the country. Some of these fresh green leafy vegetables include 'Ewuro' (Vernonia amygdalina), 'Igbo' (Solarium macrocarpon), 'Ugwu' (Talferia occidentalis) and 'Utazi' (Marsdenia latifolium) (Uzo, 1989).
The main problem in nutritional exploitation of green leafy vegetable is the presence of anti-nutrients and toxic principles. These factors are usually present in trace amount but they do have profound effects on the nutritional potential of the vegetables. The presence of anti-nutritional components; such as phytic and oxalic acid in green leafy vegetables have impairment on the efficient utilization of calcium and magnesium by formation of indigestible complexes with the mineral elements. Saponin and tannin are other anti-nutritional components of interest in vegetable studies (Messina and Messina, 1999).

Debittering is a process in which the unique bitter juice and anti-nutritional components in leafy vegetables are removed to enhance palatability. There are various primitive and innovative methods 
of debittering utilized by various ethnic groups. The interest of this study is to look at the effect of different debittering/processing methods in the elimination or reduction of specific anti-nutritional components in selected green leafy vegetables.

\section{MATERIALS AND METHODS}

\section{Sources of raw materials}

Materials(salt, potash palm oil and all the vegetable leaves; 'Ewuro' (Vernonia amygdalna), 'Igbo' (Solarium macrocarpon), 'Ugwu'(Talferia occidentalis) and 'Utazi' (Marsdenia latifolium) were purchased from Kuto and June 12 markets in Abeokuta.

\section{Sample preparation}

All the leaves were destalked where necessary. They were then rinsed thoroughly with portable water and allowed to drain.

\section{Processing/debittering methods}

All the prepared samples were treated with the same set of four treatments described below as $\mathrm{T}_{1}$, $\mathrm{T}_{2}, \mathrm{~T}_{3}$ and $\mathrm{T}_{4}$. In all, the same quantity of materials was utilized.

Squeezing vegetable with salt and water only (T)

Vegetable (10g sample) was cut into small pieces after which it was then squeezed between palms with $2 \mathrm{~g}$ of salt with $80 \mathrm{ml}$ of water to squeeze the vegetable thoroughly for $5 \mathrm{~min}$. The squeezed vegetable was then rinsed thoroughly with $100 \mathrm{ml}$ of water and the excess water from the vegetable was then drained.

\section{Hot water blanching with salt only $\left(\mathbf{T}_{2}\right)$}

The destalked vegetable (10g sample) was cut into pieces after which $2 \mathrm{~g}$ of salt was added before blanching in $80 \mathrm{ml}$ water at $70^{\circ} \mathrm{C}$ for about $5 \mathrm{~min}$. The leaves were then rinsed with $100 \mathrm{mls}$ clean water and excess water was drained from blanched vegetable.

Squeezing with salt, palm oil and water $\left(\mathbf{T}_{3}\right)$

The destalked vegetable (10g sample) was cut into pieces after which $2 \mathrm{~g}$ of salt was added and then squeezed with salt and 10ml palmoil after which it was then rinsed thoroughly with $100 \mathrm{ml}$ water. The rinsing process was repeated once with $80 \mathrm{ml}$ water, and then excess water was drained.

\section{Heating with potash and water only $\left(\mathrm{T}_{4}\right)$}

The vegetable ( $10 \mathrm{~g}$ sample) was rinsed thoroughly in water twice. $1 \mathrm{~g}$ of potash was added into boiling water $(100 \mathrm{ml})$ and allowed to dissolve. After which $10 \mathrm{~g}$ of the vegetable sample was added into the potash boiling water and left for $5 \mathrm{~min}$. The boiled sample was rinsed twice thoroughly with $100 \mathrm{mls}$ clean water and excess water was drained.

\section{Determination of antinutrients}

Oxalic acid, Saponin, Tannin and phytate contents of the raw and processed vegetable samples were determined, according to methods described by A.O.A.C. (1990).

\section{Statistical analysis}

All data obtained in triplicates were subjected to analysis of variance (ANOVA) using the SPSS statistical package (Version 10.0), (2000 edition). Means were separated with Duncan multiple ranged test (DMRT).

\section{RESULTS AND DISCUSSION}

There were significant differences $(\mathrm{p}<0.05)$ in the oxalate content of all the selected raw vegetables. Raw 'Utazi' has the highest content of oxalate ( $95.36 \mathrm{mg} / \mathrm{g}$ ) followed by raw ' $I g b o$ ' with $84.78 \mathrm{mg} /$ g. Raw 'Ewuro' and ' $U g w u$ ' had the lowest oxalate content of $75.36 \mathrm{mg} / \mathrm{g}$ and $75.81 \mathrm{mg} / \mathrm{g}$ respectively (Table 1).

There were significant differences $(\mathrm{p}<0.05)$ in the oxalate content of all the selected vegetables for all the treatments applied. "Ewuro" had the lowest oxalate content when treated with $\mathrm{T}_{1}$ (squeezing vegetable with salt and water only), $\mathrm{T}_{2}$ (hot water blanching with salt only), $\mathrm{T}_{3}$ (squeezing with salt, palm oil and water) and $\mathrm{T}_{4}$ (heating with potash and water only) thus, having the highest oxalate reduction. Treatment $\mathrm{T}_{4}$ gave the highest reduction of oxalate content (from: 78.36 to $23.1 \mathrm{mg} / \mathrm{gm}, 84.78$ to 
$36.01 \mathrm{mg} / \mathrm{gm}, 95.36$ to $25.33 \mathrm{mg} / \mathrm{gm}, 75.81$ to $26.70 \mathrm{mg} / \mathrm{gm})$ for "Eworo", "Igbo", "Utazi" and "Ugwu" respectively (Table1). This indicates that heat treatment and potash have effect on the release of oxalate from the cells of the vegetables. The reduction by (hot water blanching with salt only) was higher than that of squeezing with salt, palm oil and water. This trend holds for all the vegetables, but the percentage reduction brought about in each case differs. Figs. 1-4

There was no significance difference $(\mathrm{p}>0.05)$ in the saponin content of raw "Ewuro", "Igbo" and "Ugwu" but these were significantly different $(\mathrm{p}<0.05)$ from that of raw "Utazi" which had the highest value of 0.092 (Table 2). There was no significant difference $(\mathrm{P}>0.05)$ in the saponin contents of "Ewuro" and "Igbo" treated with Squeezing vegetable with salt and water only, which varies from $6.2 \times 10^{-2} \%$ to $6.8 \times 10^{-2} \%$ (Table 2).

There was no significant difference $(\mathrm{p}>0.05)$ in the saponin contents of all the vegetables treated with squeezing vegetable with salt and water only, hot water blanching with salt only and squeezing with salt, palmoil and water which varies from 5.4 $\times 10^{-2} \%$ and $6.2 \times 10^{-2} \%$. There was also no significant difference ( $\mathrm{p}>0.05)$ between "Utazi" and "Ugwu" treated with squeezing vegetable with salt and water only, hot water blanching with salt only and squeezing with salt, palm oil and water which ranged between $6.2 \times 10^{-2} \%$ and $6.8 \times 10^{-2} \%$, but were significantly different $(\mathrm{p}>0.05)$ from that of "Ewuro" and "Igbo" (Table 2).

When the vegetables were treated with heating with potash and water only, there was no significant difference ( $p>0.05)$ among the saponin contents of "Ewuro", "Igbo" and "Utazi" which varied between $4.3 \times 10^{-2} \%$ and $4.5 \times 10^{-2} \%$, but were significantly different $(\mathrm{p}>0.05)$ from the saponin content of "Ugwu" (5.1 x10-2\%) (Table 2).

Heating with potash and water only gave the highest reduction of saponin content for all the selected vegetables as the saponin content of all the vegetables treated with heating with potash and water only were significantly different from that of vegetables treated with squeezing vegetable with salt and water only, hot water blanching with salt only and squeezing with salt, palm oil and water. In all, "Ewuro" treated with heating with potash and water only had the lowest saponin content $\left(4.3 \times 10^{-2} \%\right)$ (Table 2).

Raw or untreated "Utazi" and "Ugwu" vegetables have lower tannin contents $(19.67 \mathrm{mg} / \mathrm{g}$ and $21.05 \mathrm{mg} / \mathrm{g}$ respectively which are not significantly different $(p>0.05)$ from each other, but are significantly different $(\mathrm{p}<0.05)$ from that of "Ewuro" and "Igbo" vegetables $(27.33 \mathrm{mg} / \mathrm{g}$ and $23.8 \mathrm{mg} / \mathrm{g}$ ) respectively (Table 3 ).

Squeezing vegetable with salt and water only reduced the tannin contents of "Utazi" and "Ugwu" vegetables to $14.57 \mathrm{mg} / \mathrm{g}$ and $14.41 \mathrm{mg} / \mathrm{g}$ respectively, which were significantly different $(\mathrm{p}<0.05)$ from that of "Ewuro" and "Igbo" $(21.34 \mathrm{mg} / \mathrm{g}$ and $19.06 \mathrm{mg} / \mathrm{g}$ respectively.

Squeezing with salt, palm oil and water, hot water blanching with salt only, and heating with potash and water only reduced the tannin content of the selected vegetables respectively, heating with potash and water only having the highest effect on tannin reduction. There was significant difference $(\mathrm{p}<0.05)$ in the tannin contents of each vegetable subjected to different treatments. " $U g w u$ " vegetable had the lowest tannin $(6.43 \mathrm{mg} / \mathrm{g})$ when treated with heating with potash and water only and was significantly different $(p<0.05)$ from all others (Table 3$)$.

There were significant differences $(\mathrm{p}<0.05)$ in the phytate contents of the unprocessed selected vegetables, with "Utazi" leaves having the lowest phytate content of $53.20 \mathrm{mg} / \mathrm{g}$ (Table 4). Squeezing vegetable with salt and water only, squeezing with salt, palm oil and water, hot water blanching with salt only, and heating with potash and water only reduced the phytate content of "Ewuro", "Igbo" and "Utazi" leaves; $(46.87 \mathrm{mg} / \mathrm{g}, 43.23 \mathrm{mg} / \mathrm{g}, 38.36 \mathrm{mg} /$ $\mathrm{g}$ and $28.77 \mathrm{mg} / \mathrm{g}),(52.05 \mathrm{mg} / \mathrm{g}, 47.31 \mathrm{mg} / \mathrm{g}$, 
$45.97 \mathrm{mg} / \mathrm{g}$ and $33.46 \mathrm{mg} / \mathrm{g}),(48.12 \mathrm{mg} / \mathrm{g}, 45.47 \mathrm{mg} /$ $\mathrm{g}, 39.94 \mathrm{mg} / \mathrm{g}$ and $34.44 \mathrm{mg} / \mathrm{g}$ ) respectively.

Treatments $\mathrm{T}_{4}, \mathrm{~T}_{3}, \mathrm{~T}_{2}$ and $\mathrm{T}_{1}$ reduced the phytate contents of "Ugwu" vegetable; $(55.13 \mathrm{mg} /$ $\mathrm{g}, 51.75 \mathrm{mg} / \mathrm{g}, 42.27 \mathrm{mg} / \mathrm{g}$ and $41.10 \mathrm{mg} / \mathrm{g}$ ) respectively. There was significant difference $(\mathrm{p}<0.05)$ in the phytate content of all the selected vegetables subjected to all the treatments, with "Ewuro" vegetable having the lowest phytate content of $28.77 \mathrm{mg} / \mathrm{g}$ when treated with $\mathrm{T}_{4}$ (Heating with potash and water only) (Table 4).

The significant differences in coefficient of variations in all the anti-nutrients in the selected vegetables corroborate results of past works. (Aregheore,1998) reported a distinct familiar differences in antinutrient constituents as indicated by the high coefficients of variation of $39.5 \%$ and $88.9 \%$ for phytate and oxalate, respectively in bitter leaf. It is noticeable that each of the leaves is high in one or two antinutrients and low in another antinutrient. Sources of variation in phytochemical contents of fresh fruit and vegetables include genetics, species of plant, and stage of growth, harvesting, post-harvest handling and storage (Sharma and Sehgal, 1990). Nevertheless percentage reduction brought about by the different processing methods is still a valid index to establish the optimum method of reducing specific antinutrient.

Generally, the tables indicate that all the methods used have significant effect on all the anti nutrients in all the selected vegetables. The tables also shows that except for saponin and tannin in 'Ewuro' hot water blanching with salt only has a significantly higher effect $(p<0.05)$ than squeezing with salt, palm oil and water on the anti nutrients in all the selected vegetables. This may indicate that hot water blanching with salt only and palm oil addition and/ or squeezing have the same effect on saponin and 'tannin' in 'Ewuro'.

It is a conventional believe that a great deal of sheer stress (via squeezing and washing) is often required to remove the antinutritional component contributing to bitter taste of vegetables before cooking or consumption. A contrary revelation from Tables 1-4 of this study is the fact the sheer stress may have effect on the other bitter plant-based compounds like quinine, phenols, flavonoids, isoflavones, terpenes, glucosinolates (which may also be present in vegetables considered in this study), it has a lesser effect on oxalate, saponin, tannin and phytate than does heat treatment and addition of potash.

Phytochemicals have been reported to be toxic at $5 \mathrm{~g}$ per serving (Messina and Messina, 1999). Considering the amount of antinutrients detected in the vegetables under study, none of them can possibly be toxic under normal meal portions.

Heating with potash and water only produced the highest percentage reduction among the processing methods, this holds for all the leaves under study (Figs.1-4). The optimum method for the reduction of all anti nutrients considered is therefore (Heating with potash and water only).

\section{CONCLUSION}

Data obtained indicate that all the selected leafy vegetables contain all the anti-nutrients under study in trace amount but different concentrations. The processing methods used in the study have effect on the anti-nutrients studied. Sheer stress brought about by squeezing and or washing of the vegetables does not significantly remove the selected antinutrient as does hot water blanching and addition of potash. Heating with potash and water only gave the highest reduction of oxalate, saponin, tannin and phytate contents of all the selected vegetables, thus could be recommended as a means of reducing these antinutrients.

\section{ACKNOWLEDGEMENTS}

The authors are grateful to the staff of Chemical Science Laboratory of the Institute of Agricultural Research And Training, Moore Plantation, Apata Ibadan. 
Table 1 Effect of processing methods on oxalate $(\mathrm{mg} / \mathrm{g})$ content of selected vegetables

\begin{tabular}{|c|c|c|c|c|c|}
\hline \multirow{3}{*}{ Vegetable } & \multicolumn{5}{|c|}{ Oxalate content (mg/g) } \\
\hline & \multicolumn{5}{|c|}{ Treatment } \\
\hline & $\mathbf{T}_{0}$ & $\mathrm{~T}_{1}$ & $\mathbf{T}_{2}$ & $\mathbf{T}_{3}$ & $\mathbf{T}_{4}$ \\
\hline 'Ewuro' & $78.36_{b(e)}$ & $39.58_{a(d)}$ & $33.37_{\mathrm{a}(\mathrm{b})}$ & $35.47_{\mathrm{a}(\mathrm{c})}$ & $23.1_{a(a)}$ \\
\hline 'Igbo' & $84.78_{c(e)}$ & $53.17_{\mathrm{d}(\mathrm{d})}$ & $39.13_{c(b)}$ & $45.25_{d(c)}$ & $36.01_{d(a)}$ \\
\hline 'Utazi' & $95.36_{\mathrm{d}(\mathrm{e})}$ & $50.01_{c(d)}$ & $36.80_{\mathrm{b}(\mathrm{b})}$ & $41.67_{c(c)}$ & $25.33_{\mathrm{b}(\mathrm{a})}$ \\
\hline 'Ugwu' & $75.81_{\mathrm{a}(\mathrm{e})}$ & $43.40_{\mathrm{b}(\mathrm{d})}$ & $35.68_{\mathrm{b}(\mathrm{b})}$ & $38.50_{\mathrm{b}(\mathrm{c})}$ & $26.70_{c(a)}$ \\
\hline
\end{tabular}

Means carrying different letters inside bracket horizontally are significantly different $(p<0.05)$. Means carrying different letters outside brackets vertically are significantly different $(p<0.05)$. $T_{0}=$ No Treatment, $T_{1}=$ Squeezing vegetable with salt and water only, $T_{2}=$ Hot water blanching with salt only, $T_{3}=$ Squeezing with salt, palm oil and water,$T_{4}=$ Heating with potash and water only

Table 2 Effect of processing methods on percentage saponin content of selected vegetables

\begin{tabular}{|c|c|c|c|c|c|}
\hline \multirow{3}{*}{ Vegetable } & \multicolumn{5}{|c|}{ Saponin content $\%\left(10^{-2}\right)$} \\
\hline & \multicolumn{5}{|c|}{ Treatment } \\
\hline & $\mathbf{T}_{0}$ & $\mathbf{T}_{1}$ & $\mathbf{T}_{2}$ & $\mathbf{T}_{3}$ & $\mathbf{T}_{4}$ \\
\hline 'Ewuro' & $7.9_{\mathrm{a}(\mathrm{c})}$ & $6.2_{a(b)}$ & $5.6_{a(b)}$ & $5.6_{a(b)}$ & $4.3_{\mathrm{a}(\mathrm{a})}$ \\
\hline 'Igbo' & $6.5_{\mathrm{a}(\mathrm{e})}$ & $6.2_{\mathrm{a}(\mathrm{d})}$ & $5.4_{a(b)}$ & $5.8_{\mathrm{a}(\mathrm{c})}$ & $4.5_{\mathrm{a}(\mathrm{a})}$ \\
\hline 'Utazi' & $9.2_{\mathrm{b}(\mathrm{d})}$ & $6.8_{\mathrm{b}(\mathrm{d})}$ & $6.2_{\mathrm{b}(\mathrm{b})}$ & $6.4_{\mathrm{b}(\mathrm{b})}$ & $4.4_{\mathrm{a}(\mathrm{a})}$ \\
\hline 'Ugwu' & $7.5_{\mathrm{a}(\mathrm{c})}$ & $6.7_{b(b)}$ & $6.2_{\mathrm{b}(\mathrm{b})}$ & $6.4_{\mathrm{b}(\mathrm{b})}$ & $5.1_{\mathrm{b}(\mathrm{a})}$ \\
\hline
\end{tabular}

Means carrying different letters inside bracket horizontally are significantly different $(p<0.05)$. Means carrying different letters outside brackets vertically are significantly different $(p<0.05)$. $T_{0}=$ No Treatment, $T_{1}=$ Squeezing vegetable with salt and water only, $T_{2}=$ Hot water blanching with salt only, $T_{3}=$ Squeezing with salt, palm oil and water,$T_{4}=$ Heating with potash and water only 
Table 3 Effect of processing methods on tannin $((\mathrm{mg} / \mathrm{g})$ content of selected vegetables

\begin{tabular}{l|c|c|c|c|c}
\hline \multirow{2}{*}{ Vegetable } & \multicolumn{5}{|c}{ Tannin content $(\mathbf{m g} / \mathbf{g})$} \\
\cline { 2 - 6 } & \multicolumn{5}{|c}{ Treatment } \\
\cline { 2 - 6 } & $\mathbf{T}_{\mathbf{0}}$ & $\mathbf{T}_{1}$ & $\mathbf{T}_{2}$ & $\mathbf{T}_{\mathbf{3}}$ & $\mathbf{T}_{4}$ \\
\hline 'Ewuro' & $27.33_{\mathrm{c}(\mathrm{e})}$ & $21.34_{\mathrm{c}(\mathrm{d})}$ & $14.04_{\mathrm{c}(\mathrm{b})}$ & $15.45_{\mathrm{b}(\mathrm{c})}$ & $9.30_{\mathrm{c}(\mathrm{a})}$ \\
'Igbo' & $23 . .85_{\mathrm{b}(\mathrm{e})}$ & $19.06_{\mathrm{b}(\mathrm{d})}$ & $11.98_{\mathrm{b}(\mathrm{b})}$ & $14.87_{\mathrm{b}(\mathrm{c})}$ & $9.52_{\mathrm{c}(\mathrm{a})}$ \\
'Utazi' & $19.67_{\mathrm{a}(\mathrm{d})}$ & $14.57_{\mathrm{a}(\mathrm{c})}$ & $11.61_{\mathrm{b}(\mathrm{b})}$ & $13.43_{\mathrm{a}(\mathrm{c})}$ & $7.66_{\mathrm{b}(\mathrm{a})}$ \\
'Ugwu' & $21.05_{\mathrm{a}(\mathrm{d})}$ & $14.41_{\mathrm{a}(\mathrm{c})}$ & $9.82_{\mathrm{a}(\mathrm{b})}$ & $13.20_{\mathrm{a}(\mathrm{c})}$ & $6.43_{\mathrm{a}(\mathrm{a})}$ \\
\hline
\end{tabular}

Means carrying different letters inside bracket horizontally are significantly different $(p<0.05)$. Means carrying different letters outside brackets vertically are significantly different $(p<0.05)$. $\mathrm{T}_{0}=$ No Treatment, $\mathrm{T}_{1}=$ Squeezing vegetable with salt and water only, $\mathrm{T}_{2}=$ Hot water blanching with salt only, $\mathrm{T}_{3}=$ Squeezing with salt, palm oil and water, $\mathrm{T}_{4}=$ Heating with potash and water only

Table 4 Effect of Processing methods on phytate $(\mathrm{mg} / \mathrm{g})$ content of selected vegetables

\begin{tabular}{l|c|c|c|c|c}
\hline \multirow{2}{*}{ Vegetable } & \multicolumn{5}{|c}{ Phytate content (mg/g) } \\
\cline { 2 - 6 } & \multicolumn{5}{|c}{ Treatment } \\
\cline { 2 - 6 } & $\mathbf{T}_{\mathbf{0}}$ & $\mathbf{T}_{1}$ & $\mathbf{T}_{2}$ & $\mathbf{T}_{3}$ & $\mathbf{T}_{4}$ \\
\hline 'Ewuro' & $55.24_{\mathrm{b}(\mathrm{c})}$ & $46.87_{\mathrm{b}(\mathrm{d})}$ & $38.36_{\mathrm{a}(\mathrm{b})}$ & $43.23_{\mathrm{a}(\mathrm{c})}$ & $28.77_{\mathrm{a}(\mathrm{a})}$ \\
'Igbo' & $58.81_{\mathrm{c}(\mathrm{d})}$ & $52.05_{\mathrm{c}(\mathrm{c})}$ & $45.97_{\mathrm{b}(\mathrm{b})}$ & $47.31_{\mathrm{c}(\mathrm{b})}$ & $33.46_{\mathrm{b}(\mathrm{a})}$ \\
'Utazi' & $53.20_{\mathrm{a}(\mathrm{c})}$ & $48.12_{\mathrm{b}(\mathrm{d})}$ & $39.94_{\mathrm{a}(\mathrm{b})}$ & $45.47_{\mathrm{b}(\mathrm{c})}$ & $34.44_{\mathrm{b}(\mathrm{a})}$ \\
'Ugwu' & $60.80_{\mathrm{d}(\mathrm{c})}$ & $41.10_{\mathrm{a}(\mathrm{a})}$ & $51.75_{\mathrm{c}(\mathrm{c})}$ & $55.13_{\mathrm{d}(\mathrm{d})}$ & $42.27_{\mathrm{c}(\mathrm{b})}$ \\
\hline
\end{tabular}

Means carrying different letters inside bracket horizontally are significantly different $(p<0.05)$. Means carrying different letters outside brackets vertically are significantly different $(p<0.05)$. $\mathrm{T}_{0}=$ No Treatment, $\mathrm{T}_{1}=$ Squeezing vegetable with salt and water only, $\mathrm{T}_{2}=$ Hot water blanching with salt only, $\mathrm{T}_{3}=$ Squeezing with salt, palm oil and water, $\mathrm{T}_{4}=$ Heating with potash and water only 


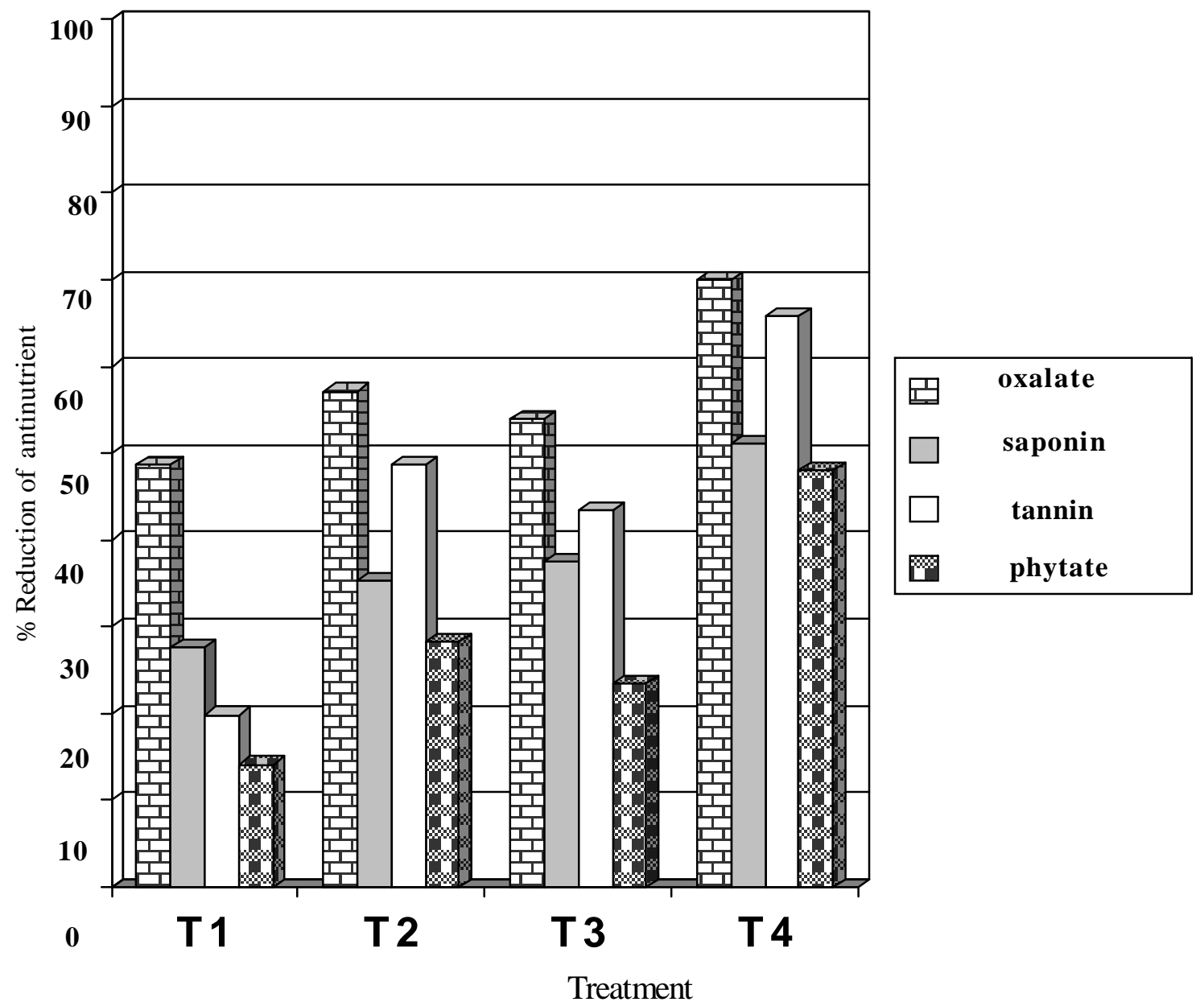

Fig 1: Percentage reduction in antinurents of "Ewuro" 


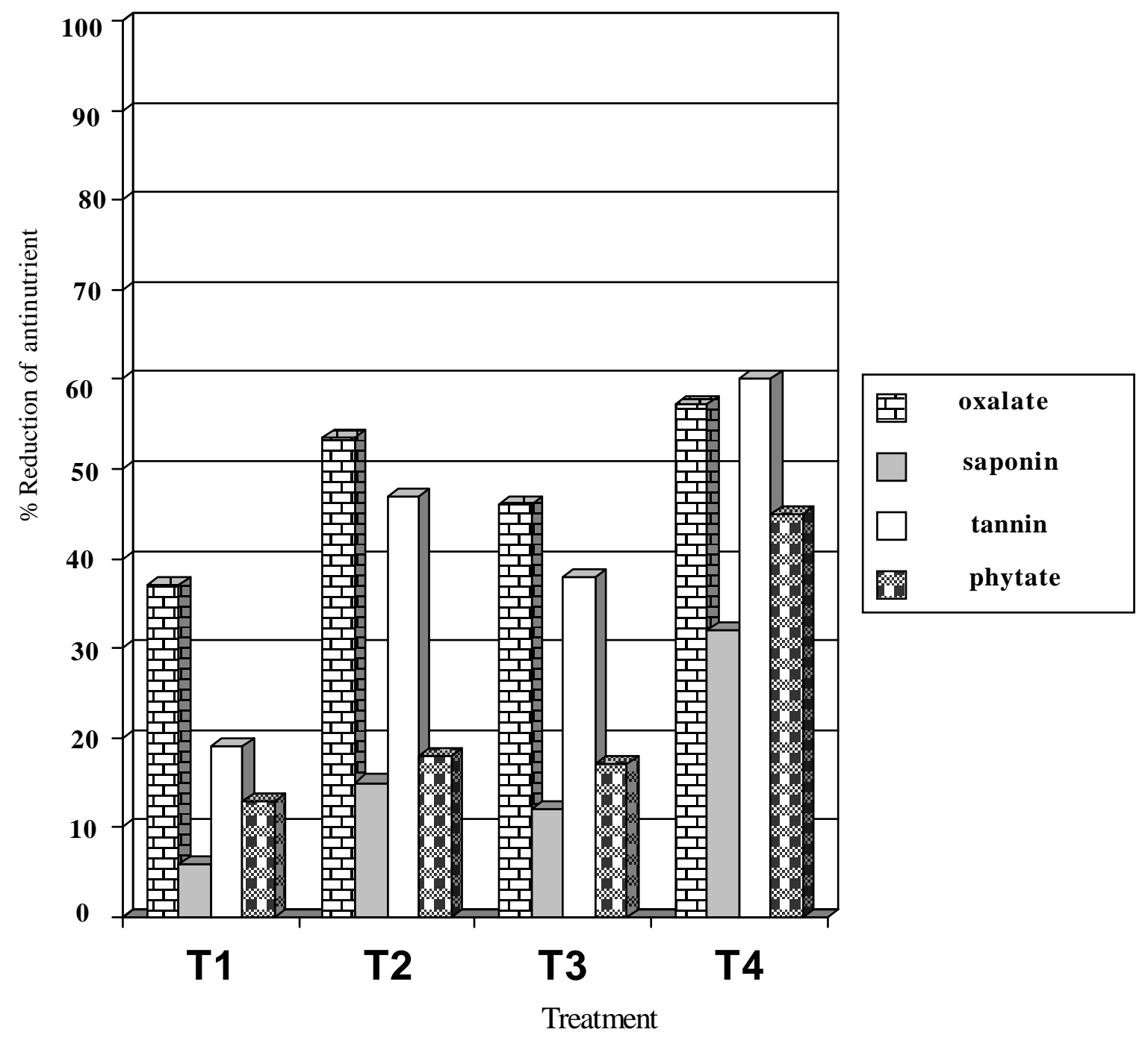

Fig 2: Percentage reduction in antinurents of "Igbo" 


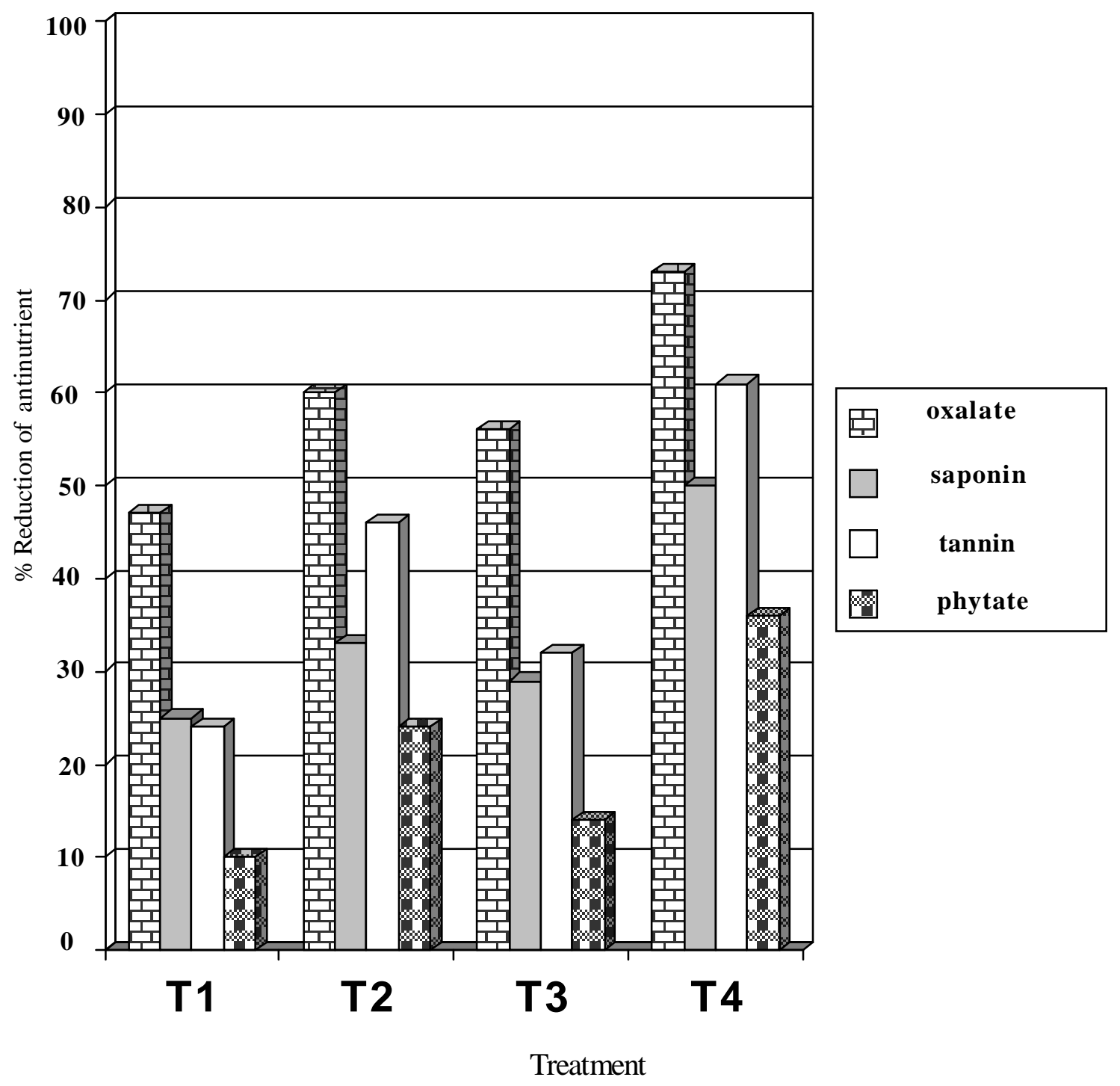

Fig 3: Percentage reduction in antinurents of "Utazi" 


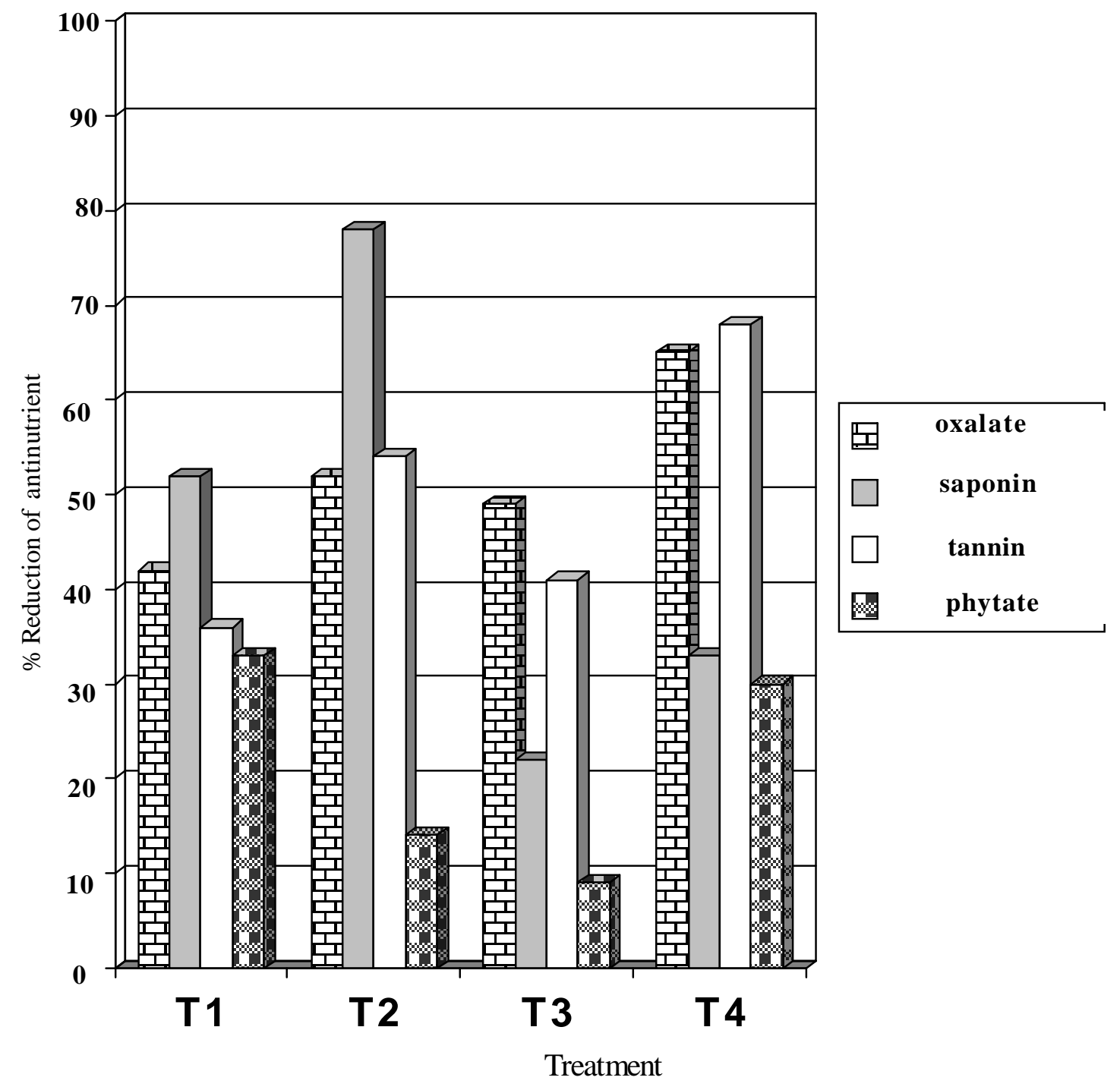

Fig 4: Percentage reduction in antinurents of " $U g w u$ " 


\section{REFERENCES}

A.O.A.C (1990): Official methods of analysis $2^{\text {nd }}$ edition. Association of Official Analytical Chemists. Washington D.C. p 21-27

Aregheore, E. M. (1998) : Chemical composition, nutritive value and preference of goats for bitter leaf (Vernonia amygdalina) as a browse plant. Scientica Agriculturae Bohemica 29(3/4): 213221. URL/http//www.ask.com

Messina M and Messina V. (1999) : A contributing paper to cancer resource foundation bulletin, U.S.A 1999 Feb 1;59(3):602-6. (URL// httpwww.google.com)
Ihekoronye A. I., and Ngoddy P.O. (1985) : Integrated Food Science and Technology for The Tropics, $2^{\text {nd }}$ Edition. Macmillan Publishers, London p. 293-295.

Uzo J. O. (1989) : Vegetable crops in Nigeria's agriculture In: Mba, B.N and Nnanyyelugo, D.O. (Eds.). Food Crops Production, Utilization and Nutrition, Dotam Publishers Ltd. Ibadan, Nigeria, p. 39-44.

Sharma A, and Sehgal S. (1992): Effect of domestic processing, cooking and germination on the trypsin inhibitor activity and tannin content of faba bean (Vicia faba). Plant Foods Hum Nutr 42(2):127133 